\title{
Landslide inventory, susceptibility mapping and recommendation of the mitigation measures in Nuwakot District
}

\author{
*Jagannath Joshi', Dipak Bharadwaj², Pradeep Paudyal ${ }^{3}$, and Niroj Timalsina ${ }^{4}$ \\ ${ }^{1}$ Hariyo Ban Program, CARE Nepal \\ ${ }^{2}$ Department of Soil Conservation and Watershed Management, Government of Nepal \\ ${ }^{3}$ Amrit Science Campus, Tribhuvan University, Kathmandu, Nepal \\ ${ }^{4}$ International Center for Integrated Mountain Development, Kathmandu, Nepal \\ *(Corresponding email: Jagannath.Joshi@care.org)
}

\begin{abstract}
Nepal earthquake of $25^{\text {th }}$ April 2015 and subsequent big aftershocks impacted people, land, and water resources significantly. Following the devastating earthquake, land and water management has become one of the primary focus of the Government of Nepal as these resources are foundations of people's livelihood and prosperity. The weakened, cracked, and destabilized slopes and surfaces due to the earthquake become even more susceptible to landslides that can be aggravated due to rainfall and inappropriate anthropogenic activities. Due to the devastating earthquake, 31 districts of Nepal out of 75 were affected with 14 being severely affected resulted huge loss of human life, property, and ecosystem services. These 14 districts were categorized as severely hit and crisis hit districts by the post disaster need assessment (PDNA) carried out by Government of Nepal. Nuwakot district is one of the severely hit district. In order to reduce vulnerability and/or threat of potential landslide disasters and protect local people, infrastructures, land and water resources from potential landslide disaster, identification of the most susceptible slopes as well as treatment and mitigation of the most critical landslides deemed essential. This study has identified the landslides and its impact within different VDCs of Nuwakot district. The mitigation measures for the urgent and treatable landslides are purposed with the tentative estimation of the cost and prioritized them based on the social, environmental and economic criteria. Out of 542 landslides identified, 105 landslides were studied in detail based on social and physical risk. The study showed that the northern part of the district is more susceptible to landslides and consequent disaster. VDCs like Bhalche, Ghyangphedi, Salme, Urleni, Kimlang, Lachyang, Ralukadevi are more susceptible to the landslides in Nuwakot district.
\end{abstract}

Received: 13 July 2016

Revision accepted: 11 June 2017

\section{INTRODUCTION}

Landslide is most prominent hazard in mountainous region in all around the world (Gerrard 1994; Larsen 2001). A global data set of fatalities from non-seismically triggered landslides that resulted in loss of life between 2004 and 2010 reported that a total of 2620 fatal landslides were recorded worldwide during the 7 years period of the study, causing a total of 32,322 recorded fatalities (roughly 4600 people each year), the majority of human losses occur in Asia, especially along the Himalayan Arc (Petley 2012). Landslides are one of the main natural disasters responsible for huge social and economic losses in Nepal. The number of deaths due to landslide and flood has remained significantly high (Dhital 2005). Floods and landslides are common during the monsoon season and invariably kill a large number of people and destroy or damage properties. The flood and landslide disasters of 1993, 2008 and 2014 are the most devastating which have caused enormous loss to human lives and physical properties. According to the data of Ministry of Home Affairs, the floods and landslide disasters of the year 2013 claimed the lives of 219 people and 241 people lost their lives in the year 2014 (MoHA and DPNet 2015). Identification of landslide susceptible slopes/areas and effective prevention works help preparedness and mitigate the impact of landslide disaster which begins with landslide susceptibility mapping. Landslide susceptibility is defined as likelihood of landslide occurring in an area controlled by their local terrain conditions (Brabb 1984). Thus produced susceptible maps would be supportive tools to identify potentially future landslide occurrence area.

In Nepal, urgency of landslide susceptible areas zonation was realized after catastrophic earthquake of $25^{\text {th }}$ April 2015. Due to earthquake 31 districts were affected, out of which 14 districts were categorized as severely hit and crisis hit districts by the Post Disaster Need Assessment (PDNA) carried out by Government of Nepal. PDNA has identified seven districts namely Gorkha, Dhading, Nuwakot, Rasuwa, Sindhupalchowk, Dolakha, and Ramechhap as severely hit districts. Besides human casualties and huge economic-loss, the earthquake triggered numerous landslides which affected the lives and livelihood of local people. The weakened, cracked, and destabilized slopes and surfaces, after shaken by the main $25^{\text {th }}$ April Earthquakes and its after shocked have become even more susceptible to landslides that can be aggravated due to rainfall and by further working on those land systems. 
These landslides and accelerated soil erosion in upstream of watersheds due to rainfall/runoff or by other means may cause flooding and huge amount of sediment deposition in the downstream areas.

In post-earthquake scenario, Government of Nepal has highly prioritized the recovery works, mitigation measures and supporting people to overcome from the disaster. As land and water resources and eco systems are majorly impacted by the earthquake, many development partners are supporting on land protection and water management. Department of Soil Conservation and Watershed Management (DSCWM) has major mandates to work on the landslide treatment and mitigation measures to protect people, settlements, development infrastructures, water and land resources. Immediately after earthquake, District Soil Conservation Offices (DSCOs) started preparatory and relief works with the resources that they had and by the additional financial resources provided by Government of Nepal at the time. Then DSCWM has prioritized its works and allocated resources for the earthquake induced landslides mitigation and prevention activities.

Although different agencies has been engaged in working on the landslide inventory and hazard assessment, it has been realized that there are still gaps in terms of the reliable primary database related to the scale and types of landslides, current and possible future impacts due to landslides, urgency for the treatment, treatability of the landslides and major on recommendation for the structural and non-structural measures to treat the landslides. So before the time of implementation, government and other supporting agencies are in need to work on the landslide assessment more on identifying critical landslides, segregating landslide to be treated immediately with high priority, planning and recommendation for different conservation /mitigation measures (activities to be undertaken on critical landslides identified) in different watersheds/subwatersheds of landslide affected districts. In this context, landslide inventory with identification of their types, vulnerability status, and appropriate measures for mitigation are most crucial.

\section{STUDY AREA}

Nuwakot is one of the seven severely affected districts by earthquake of $25^{\text {th }}$ April 2015. It lies to the north of Kathmandu (Fig. 1). Trishuli River, one of the major river in the Gandaki Basin, flows through the district that drains out many small watersheds. There are numbers of landslides that were induced before and after earthquake needs to be studied for treatment or mitigation measures. mitigation measures.

\section{METHODOLOGY}

\section{Landslide inventory and classification}

Landslide inventory of pre-earthquake period (i.e., prior to Gorkha earthquake) was accomplished with digitization on Google Earth image prior to April 2015. Similarly, post- earthquake landslides were digitized from the Google Earth image, published after earthquake events. Landslides are broadly categorized into i) Landslide and erosion (Le), ii) Debris flow and erosion (De), iii) Rock fall and erosion (Fl), and iv) Complex slope failure (EDL), taking consideration of nature of mass wasting, their shape, tune, texture and area.

Location information of such extracted landslides was transferred to GPS for field verification and update. Similarly, color print of higher resolution Google image with landslide polygon were provided to field teams. During field visit all available information such as their types, geo-engineering properties of place, landslide initiated year, associated risk and possible mitigation measures were collected. Locations of all visited landslides were marked by GPS and sketches were drawn. Elements at risk, such as house unit, cultivation, school, road, bridge and others were attributed to each digitized landslide. Thus produced database were then used to update and validate the Google earth interpretation.

\section{Generation of landslide contributing parameters}

Altogether 13 landslide contributing parameters were prepared in Arc-GIS environment. These parameters are broadly categorized into four domains: i) Topographic domain (Aspect, Elevation, Relative relief, Slope gradient, Slope shape, and Topographic position index), ii) Hydrological domain (Annual rainfall, Drainage density, Topographic wetness index, and Stream power index), iii) Anthropogenic domain (Land-use/ Land-cover and NDVI), and iv) Geology (rock/soil).

\section{Bivariate statistical analysis}

Landslide susceptibility map was prepared by using the GIS based bivariate statistical technique, which is widely accepted scientific methodology. It is common to assume that landslide occurrence is determined by landslide inducing factors, and that future landslides will occur under the same conditions as past landslides did. For this analysis, all the landslides except rock falls and slides are incorporated. The quantitative analysis used here is called the landslide index method. A weight-value for a parameter class, such as a certain lithological unit or a certain slope class is defined as the natural logarithm of the landslide density in the class divided by the landslide density in the entire map (van Westen 1997).

$$
\mathrm{Wi}=\ln \frac{\frac{\mathrm{Li}}{\mathrm{Ai}}}{\frac{\sum \mathrm{Li}}{\Sigma \mathrm{Ai}}}
$$

i.e. $\mathrm{Wi}=($ Density class/Density map $)$

where,

$\mathrm{Wi}=$ Weight assigned to certain parameters class.

Density Class $=$ the landslide density within the parameter class.

Density Map = the landslide density within the entire map.

$\mathrm{Li}=$ Area, which contain landslide, in a certain parameter class.

$\mathrm{Ai}=$ Total area, in a certain parameter class. 


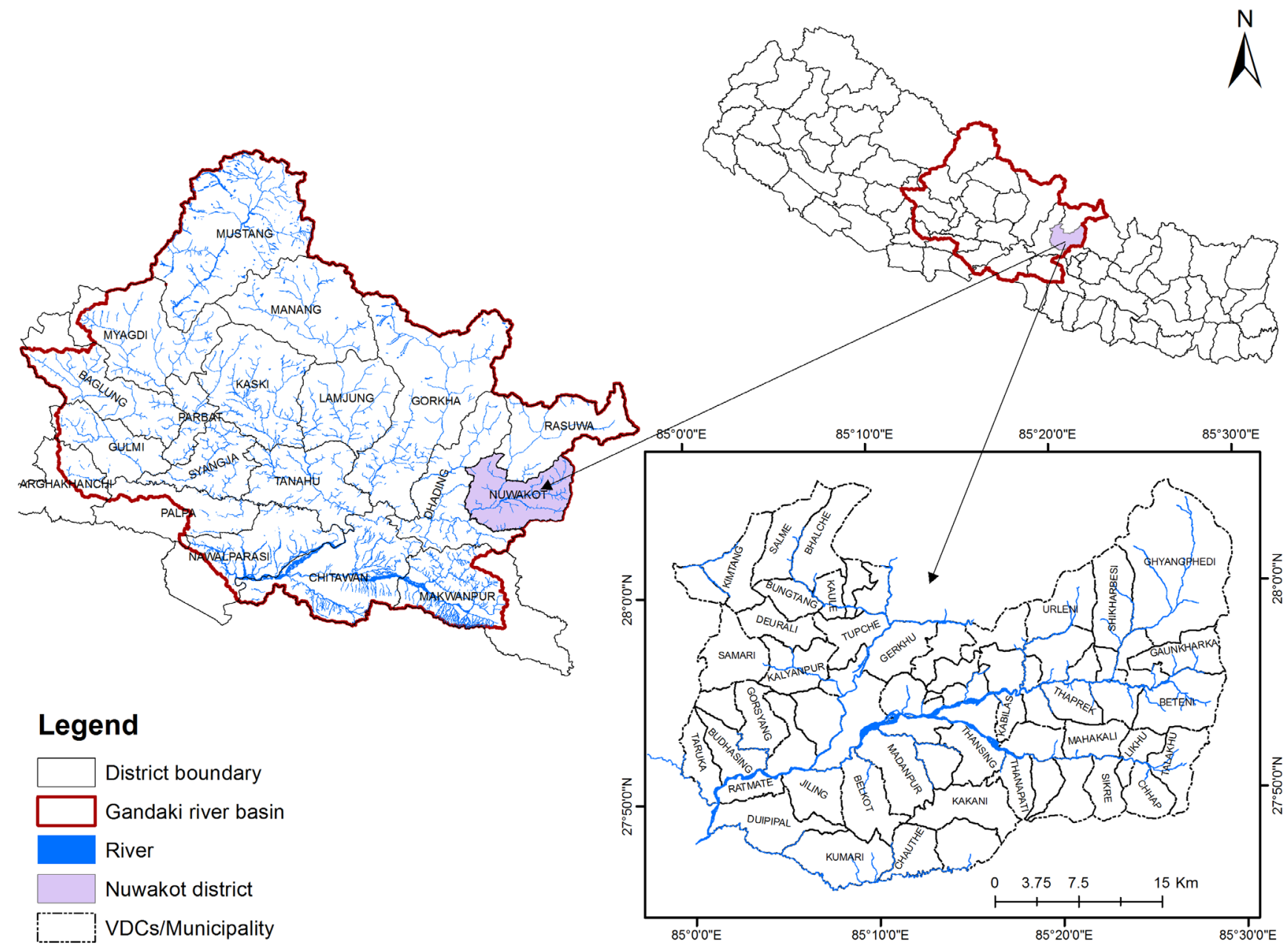

Fig. 1: Location map of the study area.

The method is based on map crossing of landslide map with a certain parameter map. Map crossing results in a cross table can be used to calculate the density of landslide per parameter class. Landslide susceptibility index (LSI) is determined by summation of each factor's ratings using equation (Lee and Pradhan 2006).

$$
\mathrm{LSI}=\sum_{\mathrm{i}=1}^{\mathrm{N}} \mathrm{Wi}
$$

Where,

$\mathrm{Wi}=$ Weight assigned to each i parameters

$\mathrm{N}=$ Total number of parameters

Then, the reclassification procedure was utilized for reclassifying the LSI map into five different landslide susceptibility zones: very low, low, moderate, high and very high.

\section{Prioritization of landslides for mitigation measures}

All the landslides are enlisted and ranked on the basis of vulnerability and treatability. This list of prioritization of landslides helps to choose the most critical one at first for the mitigation. For the purpose of landslide ranking and prioritization, a rating table was developed on the basis of seven different attributes and their respective classes (Table 1). For each attribute class, a minimum rating value of 1 and the maximum of 4 were assigned. For some complex landslides, where more than one failure type occurred, the rating value was calculated by averaging the rating of each involved class. A total rating for each landslide type was obtained by multiplying the ratings of the seven attributes listed in Table 1. For the purpose of prioritizing landslide control and mitigation works, the total rating was then arranged in an ascending order and the landslides were prioritized accordingly.

\section{RESULTS AND DISCUSSION}

\section{Landslide distribution}

A total number of 542 landslides are mapped in the study area (Fig. 2). These landslides range from very small with an area of $0.1 \mathrm{sq}$. $\mathrm{m}$. to very large with an area more than 140,000 sq. $\mathrm{m}$. The study shows that there was a dominance of complex landslides in the study area before earthquake, while the shallow rock falls have been mapped in large numbers after the Gorkha earthquake 2015 (Fig. 3). 
Joshi et al.

Table 1: Rating scheme for ranking landslides based on their attribute classes

\begin{tabular}{|l|l|l|l|l|}
\hline Attribute & \multicolumn{4}{|c|}{ Class } \\
\hline Landslide type & $\begin{array}{l}\text { Gully erosion and } \\
\text { Landslide (Le) }\end{array}$ & $\begin{array}{l}\text { Debris flow, Debris slide, } \\
\text { and erosion (De) }\end{array}$ & $\begin{array}{l}\text { Rock fall/rock slide, } \\
\text { wedge, toppling (Fl) }\end{array}$ & $\begin{array}{l}\text { Complex slide } \\
\text { (EDL) }\end{array}$ \\
\hline Landslide depth & Up to $3 \mathrm{~m}$ & $3-5 \mathrm{~m}$ & $5-7 \mathrm{~m}$ & More than $7 \mathrm{~m}$ \\
\hline Hydrology & Dry & $\begin{array}{l}\text { Wet, spring, seeps, } \\
\text { saturated ground }\end{array}$ & & \\
\hline Land use or land cover & $\begin{array}{l}\text { Cultivated land, paddy } \\
\text { field }\end{array}$ & Forest, bushes, grassland & Barren land & \\
\hline $\begin{array}{l}\text { Proximity to village, } \\
\text { infrastructure, or } \\
\text { property }\end{array}$ & $\begin{array}{l}\text { Village, settlement, } \\
\text { town }\end{array}$ & $\begin{array}{l}\text { Cultivated land (dry or } \\
\text { wet) }\end{array}$ & Road or trail & $\begin{array}{l}\text { Others (hydropower } \\
\text { project site, tunnel } \\
\text { portal, etc.) }\end{array}$ \\
\hline Treatability & Easily Treatable & Moderately Treatable & Difficultly Treatable & \\
\hline Rating for each class & 1 & 2 & 3 & 4 \\
\hline
\end{tabular}

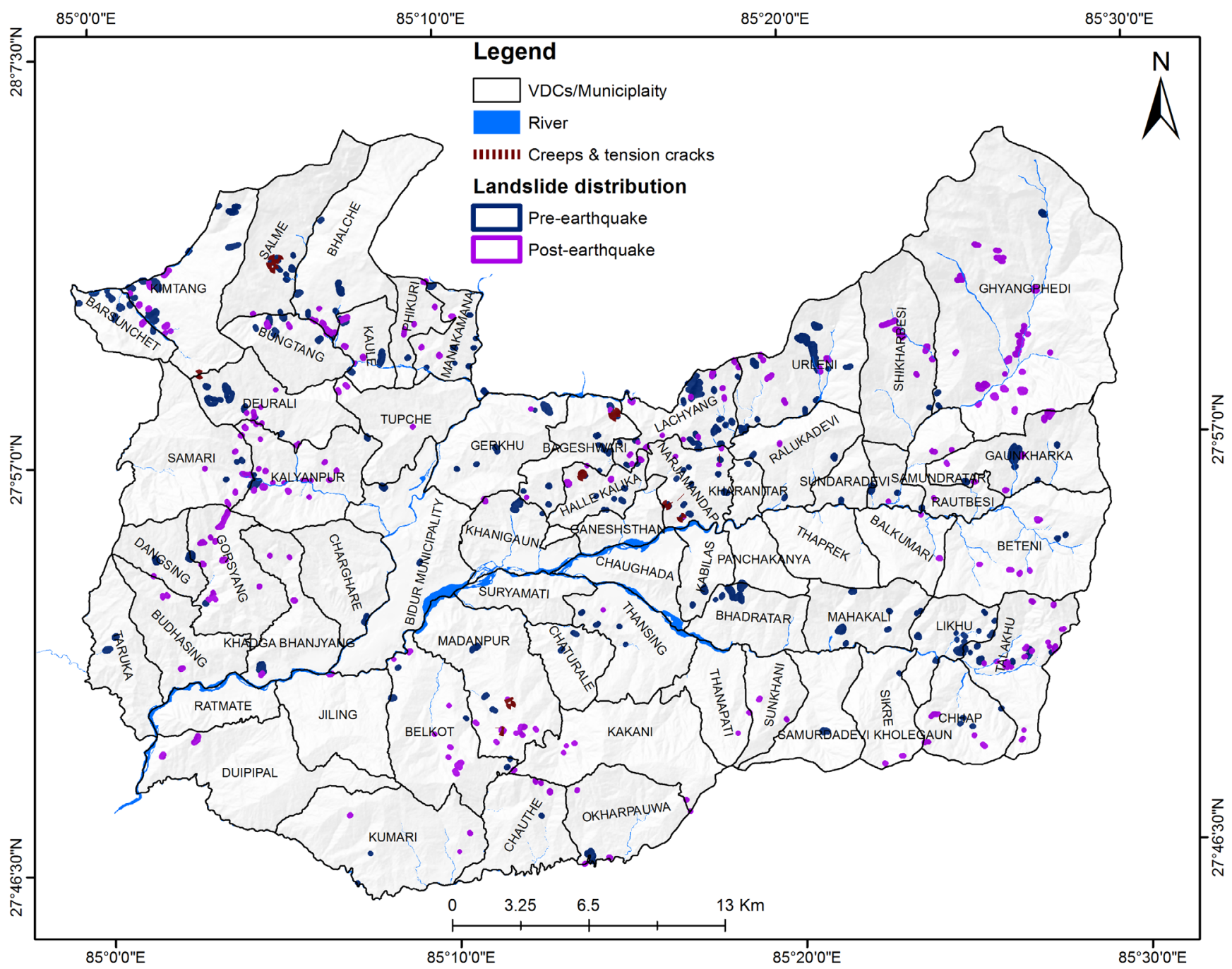

Fig. 2: Spatial distribution of landslides in study area.

\section{Causative factors and landslide susceptibility map}

There is a relationship between landslide occurrence and internal classes of each causative parameters. The result shows that most of the landslides $(45.3 \%$ of total landslides) occurred in intermediate slope class or between 25-35 degree slopes (Fig. 4). Similarly, most of the landslides (i.e., 51.7\%) occurred in the concave slope terrain, which might be favorable for landslides because of holding moisture effectively. There is high occurrence of landslides in cultivated land (31.1\%), 


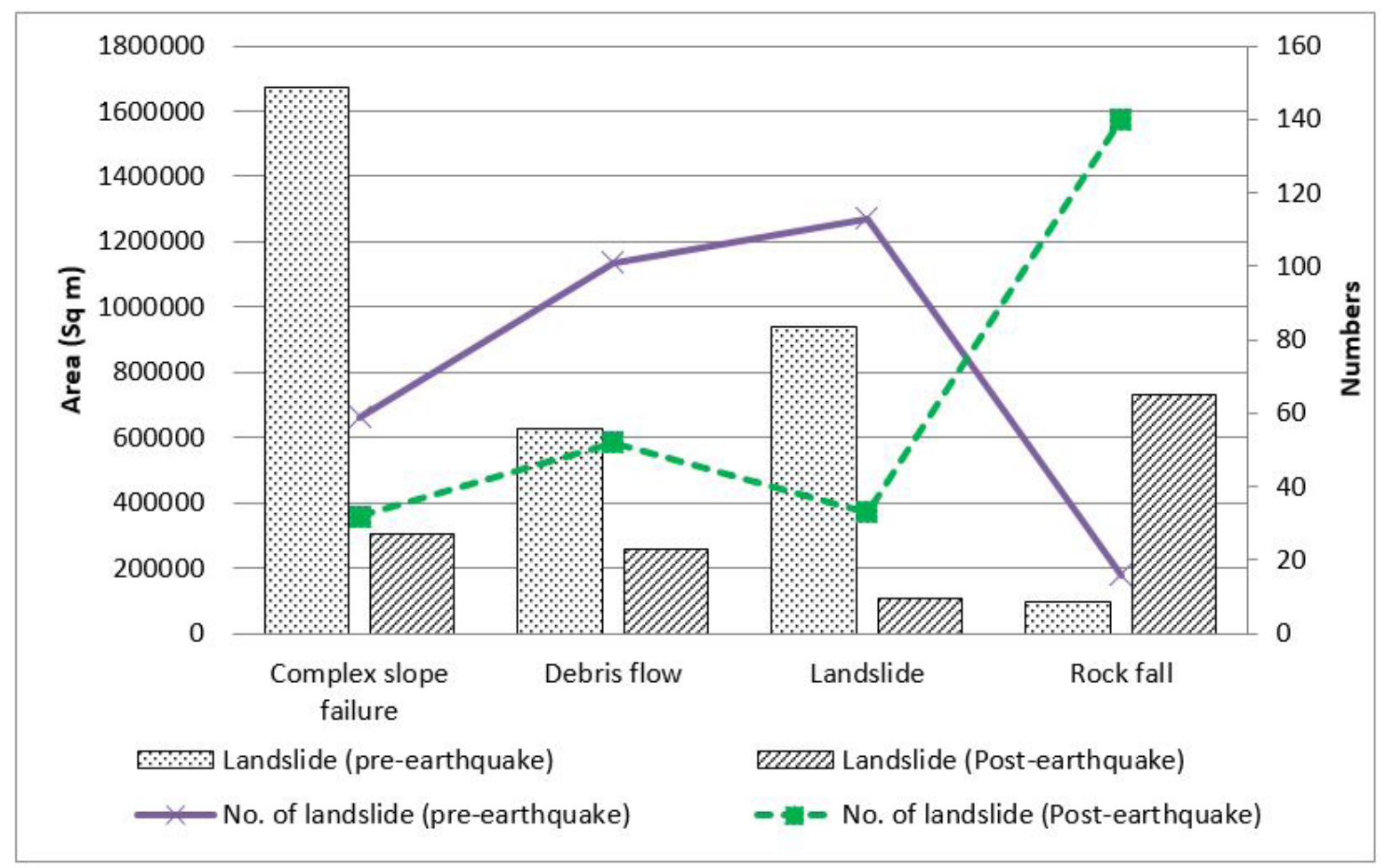

Fig. 3: Distribution of landslides in Nuwakot district based on their types and time of occurrence.

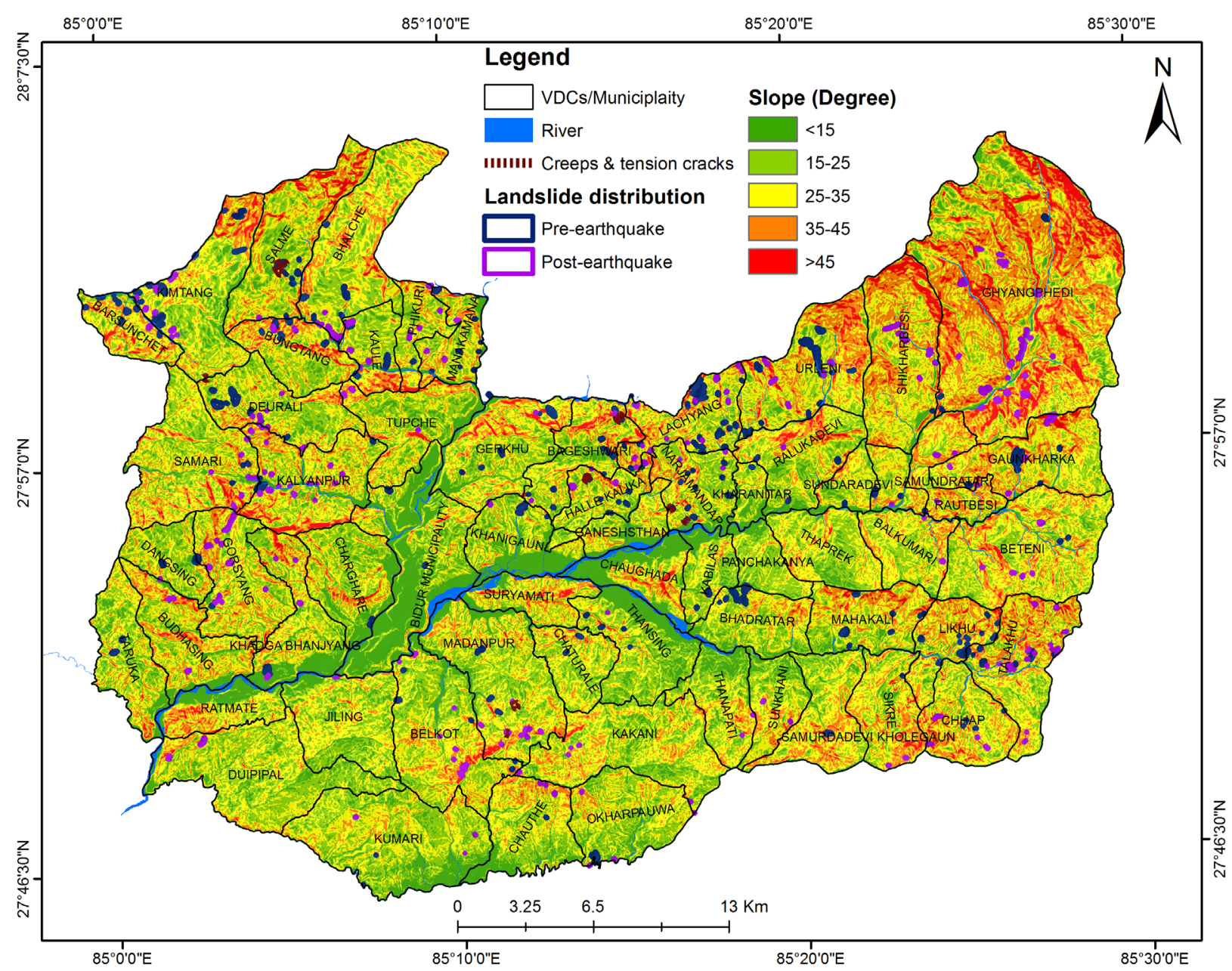

Fig. 4: Spatial distribution of slope gradient and relation with landslides. 
Joshi et al.

Table 2: Calculated weights of each parameter for landslide susceptibility.

\begin{tabular}{|c|c|c|c|c|}
\hline Parameters & Parameter class & Area (sq Km) & Landslide occurrence (sq. Km) & Weight \\
\hline \multirow[t]{8}{*}{ Aspect } & $\mathrm{N}$ & 133.7 & \begin{tabular}{|l|l|}
0.21 \\
\end{tabular} & -0.5 \\
\hline & $\mathrm{NE}$ & 122.11 & 0.13 & -0.93 \\
\hline & E & 128.57 & 0.24 & -0.33 \\
\hline & SE & 169.85 & 0.58 & 0.26 \\
\hline & $\mathrm{S}$ & 180.68 & 0.76 & 0.47 \\
\hline & SW & 170.05 & 0.65 & 0.37 \\
\hline & W & 147.31 & 0.33 & -0.17 \\
\hline & $\mathrm{NW}$ & 144.88 & 0.25 & -0.44 \\
\hline \multirow[t]{5}{*}{ Elevation $(\mathrm{m})$} & $<800$ & 206.74 & 0.19 & -1.05 \\
\hline & $800-1500$ & 507.04 & 1.74 & 0.27 \\
\hline & $1500-2200$ & 305.18 & 0.92 & 0.13 \\
\hline & \begin{tabular}{|l|}
$2200-2900$ \\
\end{tabular} & 102.19 & 0.28 & 0.03 \\
\hline & $>2900$ & 76 & 0.03 & -1.98 \\
\hline \multirow[t]{5}{*}{ Relief } & $\mid 1.0-140.6$ & 121.24 & 0.1 & -1.14 \\
\hline & $140.7-226.5$ & 408.07 & 0.8 & -0.3 \\
\hline & $226.52-305.97$ & 393.06 & 1.31 & 0.24 \\
\hline & 305.98-414.04 & 212.21 & 0.8 & 0.36 \\
\hline & $414.05-814.54$ & 62.58 & 0.15 & -0.12 \\
\hline \multirow[t]{5}{*}{ Slope gradient (Degree) } & $<15$ & 167.09 & \begin{tabular}{|l|l|}
0.11 \\
\end{tabular} & -1.41 \\
\hline & $15-25$ & 344.84 & 0.51 & -0.57 \\
\hline & $25-35$ & 432.51 & 1.43 & 0.23 \\
\hline & $35-45$ & 208.16 & 0.89 & 0.49 \\
\hline & $>45$ & 44.57 & 0.21 & 0.58 \\
\hline \multirow[t]{3}{*}{ Plan Curvature } & Concave & 459.71 & 1.63 & 0.29 \\
\hline & Flat & 238.69 & 0.5 & -0.23 \\
\hline & Convex & 498.75 & 1.03 & -0.24 \\
\hline \multirow[t]{5}{*}{ Topographic Position Index } & $0.067-0.341$ & 66.56 & 0.07 & -0.94 \\
\hline & $0.342-0.442$ & 230.97 & 0.56 & -0.08 \\
\hline & $0.443-0.513$ & 435.35 & 1.28 & 0.11 \\
\hline & 0.514-0.591 & 368.4 & 1.1 & 0.12 \\
\hline & $0.592-0.925$ & 95.79 & 0.15 & -0.52 \\
\hline \multirow[t]{5}{*}{ Annual rainfall } & $2110-2310$ & 173.97 & 0.13 & -1.27 \\
\hline & $2310.1-2475$ & 423.56 & 0.71 & -0.46 \\
\hline & $2475.1-2675$ & 342.33 & 1.28 & 0.35 \\
\hline & 2675.1-2925 & 170.87 & 0.55 & 0.2 \\
\hline & 2925.1-3175 & 81.66 & 0.48 & 0.8 \\
\hline \multirow[t]{5}{*}{ Drainage Density $(\mathrm{Km} / \mathrm{Sq} \mathrm{km})$} & $1.15-2.72$ & 199.79 & 0.48 & -0.09 \\
\hline & $2.73-3.57$ & 410.07 & 1.67 & 0.43 \\
\hline & $3.58-4.7$ & 340.56 & 0.88 & -0.02 \\
\hline & $4.71-6.29$ & 114.76 & 0.1 & -1.09 \\
\hline & 6.3-8.16 & 131.97 & \begin{tabular}{|l|l|}
0.02 \\
\end{tabular} & -2.67 \\
\hline \multirow[t]{5}{*}{ Topographic Wetness Index } & -3.56 & 157.84 & 0.25 & -0.5 \\
\hline & -3.35 & 432.11 & 1.22 & 0.07 \\
\hline & -2.082 & 447.49 & 1.26 & 0.06 \\
\hline & 0.253-4.02 & 136.91 & 0.37 & 0.04 \\
\hline & \begin{tabular}{|l|}
$4.03-18$ \\
\end{tabular} & 22.81 & 0.05 & -0.22 \\
\hline
\end{tabular}


Table 2: (Contd.)

\begin{tabular}{|c|c|c|c|c|}
\hline Parameters & Parameter class & Area (sq Km) & Landslide occurrence (sq. Km) & Weight \\
\hline \multirow[t]{5}{*}{ Stream Power Index } & -6.33 & 22.22 & 0.02 & -1.18 \\
\hline & -3.36 & 141.44 & 0.24 & -0.46 \\
\hline & $1.1-4.66$ & 408.24 & 0.76 & -0.35 \\
\hline & $4.67-7.21$ & 532.94 & 1.77 & 0.23 \\
\hline & $7.22-17.4$ & 92.32 & 0.37 & 0.41 \\
\hline \multirow[t]{11}{*}{ Land cover } & Barren Land & 36.15 & 0.12 & 1.71 \\
\hline & Pond or Lake & 0.19 & 0 & -1.76 \\
\hline & Sand & 14.94 & 0.01 & -1.76 \\
\hline & Grassland & 75.38 & 0.78 & 1.36 \\
\hline & Forest & 279.45 & 0.38 & -0.67 \\
\hline & Cuting/Cliff & 1.51 & 0.21 & 2.36 \\
\hline & Cultivated Land & 647.42 & 0.98 & -0.55 \\
\hline & Shrub/Bushes & 135.55 & 0.68 & 0.64 \\
\hline & River & 5.76 & 0 & -1.76 \\
\hline & Orchard & 0.43 & 0 & -1.76 \\
\hline & Plantation Area & 0.39 & 0 & -1.76 \\
\hline \multirow[t]{5}{*}{ NDVI } & \begin{tabular}{|l|}
-0.0987 \\
\end{tabular} & 436.01 & 0.88 & -0.27 \\
\hline & -0.0172 & 324.68 & 0.69 & -0.21 \\
\hline & -0.019 & 232.62 & 0.69 & 0.12 \\
\hline & -0.0221 & 155.29 & 0.58 & 0.34 \\
\hline & 0.016-0.128 & 48.56 & 0.32 & 0.91 \\
\hline \multirow[t]{12}{*}{ Geology } & Formation I & 439.47 & 1.22 & 0.06 \\
\hline & Kuncha Formation & 390.23 & 1.45 & 0.35 \\
\hline & Ulleri Augen Gneiss & 5.21 & 0 & -0.19 \\
\hline & Dhading Dolomite & 3.93 & 0 & -0.19 \\
\hline & \begin{tabular}{|l|} 
Ghandruk Quartzite \\
\end{tabular} & 20.39 & 0.12 & 0.78 \\
\hline & $\mathrm{BB}$ & 78.79 & 0.25 & 0.18 \\
\hline & Limestone & 16.68 & 0.01 & -1.52 \\
\hline & Higher Himalayan Gneiss & 233.45 & 0.1 & -1.83 \\
\hline & Formation II & 3.49 & 0 & -1.53 \\
\hline & Upper Quartzite & 1.36 & 0 & -0.19 \\
\hline & Unknown & 2.22 & 0 & -0.19 \\
\hline & Tistung Formation & 1.93 & 0 & -0.19 \\
\hline
\end{tabular}

followed by grassland (24.7\%), and shrub /bush lands, where $21.6 \%$ of landslides have been occurred. Intermediate slope class seems more favorable for the landslides because it is very close to the internal frictional angle of most of the rock and soil materials in the hilly region of Nepal. The weight assured by the classes of each parameter directly indicates its importance in causing landslide. If the weight is positive and higher, the factor is favorable for landslide, whereas if it is negative, it is unfavorable. For instance, cutting feature in land cover acquired the highest positive weight among all which indicates that previous slope failure areas have maximum chances of potential failure (Table 2). As landslide susceptible zonation is a product of multiple factors summed up to their weightage values, the landslide susceptibility map shows the combined effect of all the landslide causative factors. The landslide susceptibility map of the study area was prepared using landslide susceptibility index (LSI) method, in which the weightage for each parameter was calculated by crossing them with different types of landslides except rock falls and slides. The landslide susceptibility map (Fig. 5) is categorized into five classes to show the different levels of landslide hazard in the study area. About $16 \%$ of the total area lies under very high landslide susceptibility zone in the study area (Table 3 ).

Table 3: Distribution of landslide susceptibility class

\begin{tabular}{|l|l|l|}
\hline Susceptibility Class & Area $(\mathbf{s q} \mathbf{~ k m )}$ & Percentage (\%) \\
\hline Very low & 183.34 & 15.36 \\
\hline Low & 234.35 & 19.63 \\
\hline Moderate & 324.97 & 27.22 \\
\hline High & 261.81 & 21.93 \\
\hline Very high & 189.21 & 15.85 \\
\hline
\end{tabular}




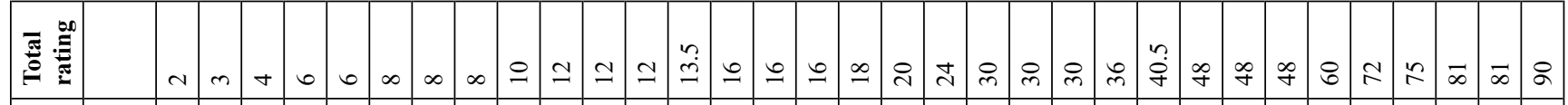

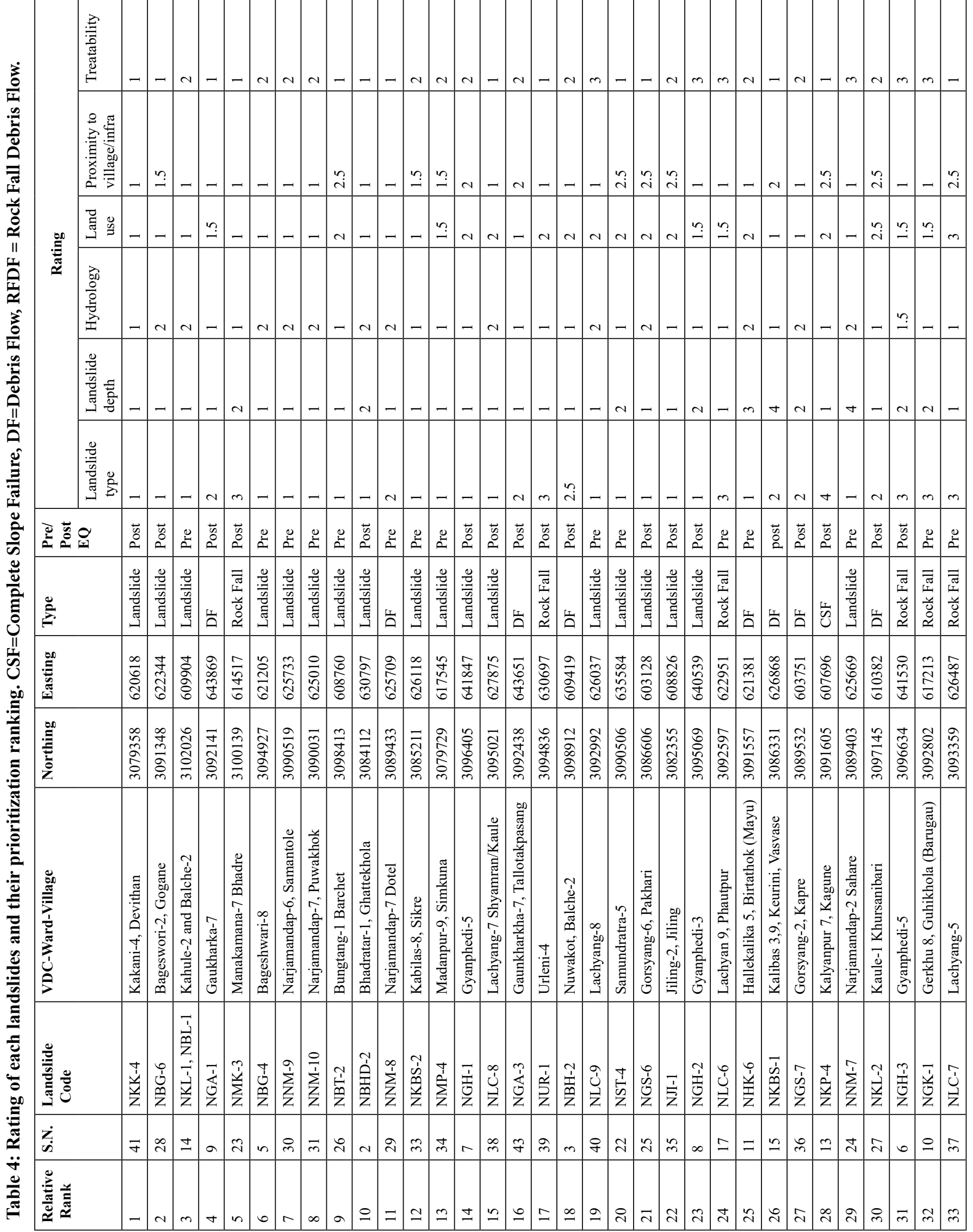




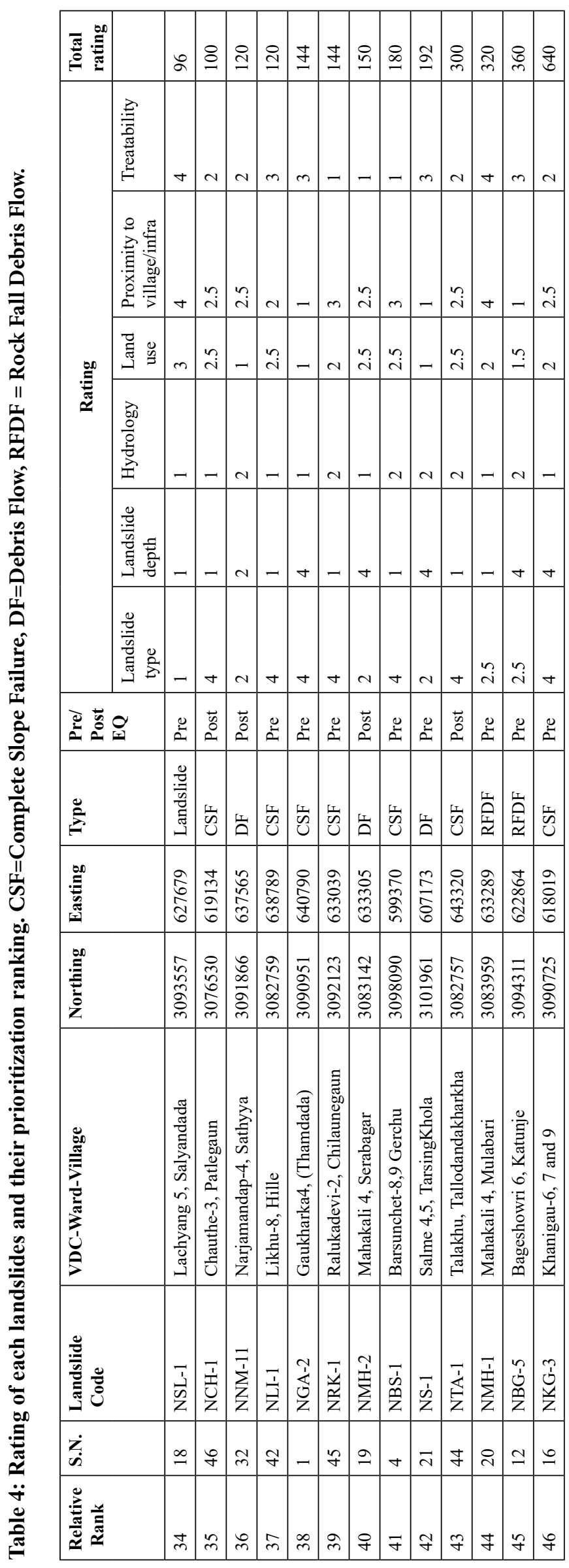

\section{Landslide ranking, prioritization, and recommen- dation of mitigation measures}

A total of 46 landslides are mapped to be more critical based on their exposure to physical and social risks. To make more practical and ease to treat or mitigate these landslides, they are ranked in an order of urgency. The prioritized landslides with their relative rank are presented in Table 4. Though it is necessary to carry out detailed site survey before the implementation of mitigation measures, the present study gives an overview of treatment or mitigation measures. The details of landslide control measures can also be referred from Deoja et al. (1991) and Howell (1999). Landslide treatment or mitigation measures are designed and costs are estimated by following guidelines that was approved by Department of Soil Conservation and Watershed Management (DSCWM 2016). Site specific control or mitigation measures are recommended (Table 5; Fig. 6). Since these recommendations are made based on preliminary field survey alone, a detailed site investigation will be required before implementation of mitigation measures.

\section{CONCLUSIONS}

Different types of landslides (rock falls, debris flows, rock slides, and debris falls) caused by 2015 Gorkha earthquake as well as torrential rainfalls during the monsoon had damaging effects and caused serious threats to life and property in the Nuwakot district. The damage was confined mainly to steep cut slopes (by river scouring and road cut), rock cliffs, and erosive gullies with fractured rock or colluvium. Most of the triggered slides comprise shallow (less than $5 \mathrm{~m}$ deep) and short sliding part but the run out materials reach quite far.

Landslide susceptibility map is a result of combination of various landslide causative parameters, such as existing landslides, hydrological and wetness index, land use and vegetative index, geological setting, topographical and morphological setting that depict the landslide susceptible areas in the study area. It excludes the existing rock falls and rock slides. Rock fall susceptibility map shows the potential rock fall and/or slide sides in the study area. Owing to the lack of good DEM and the temporal landslide occurrence data and rainfall intensities, it is not possible to prepare event based landslide hazard map. On the other hand, the entire region suffered from almost complete building collapse due to earthquake shaking. So, physical vulnerability and risk assessment of the district was not appropriate. Instead, a proper methodology for social vulnerability analysis is presented.

A proper landslide ranking and prioritization is proposed. There are some essential mitigation measures suggested for prioritized landslides based on field survey with satellite image analysis that may require further modification and detailed survey before the implementation of treatment or mitigation activities. 
Table 5: Landslides in the study area and proposed mitigation measures

\begin{tabular}{|c|c|c|c|c|c|c|c|c|}
\hline \multirow[t]{3}{*}{ S.N. } & \multicolumn{2}{|c|}{ Location of landslides } & \multicolumn{6}{|c|}{ Proposed structures } \\
\hline & \multirow{2}{*}{$\begin{array}{l}\text { VDC and } \\
\text { Village } \\
\text { name }\end{array}$} & \multirow[t]{2}{*}{ Landslide ID } & \multirow{2}{*}{$\begin{array}{l}\text { Safe } \\
\text { drainage } \\
\text { chanel at } \\
\text { crown }(\mathrm{m})\end{array}$} & \multirow{2}{*}{$\begin{array}{l}\text { Check } \\
\text { dam (nos.) }\end{array}$} & \multirow{2}{*}{$\begin{array}{l}\text { Gabion wall } \\
\text { for toe } \\
\text { protection }(m)\end{array}$} & \multicolumn{3}{|c|}{ Bio-engineering (sq. m.) } \\
\hline & & & & & & $\begin{array}{l}\text { Jute } \\
\text { netting } \\
\text { works }\end{array}$ & $\begin{array}{l}\text { Grass seeds } \\
\text { broadcasting }\end{array}$ & $\begin{array}{l}\text { Medium-sized shrub } \\
\text { and tree seedlings } \\
\text { plantation }\end{array}$ \\
\hline 1 & Gaukharka 4, Beptho (Thamdada) & NGA-2 & 160 & 2 & 50 & 2000 & 1000 & 50 \\
\hline 2 & Balche-2 & NBH-2 & 150 & 0 & 0 & 0 & 4000 & 200 \\
\hline 3 & Barsunchet & NBS-1 & 25 & 0 & 25 & 0 & 300 & 0 \\
\hline 4 & Bageshwari-8 & NBG-4 & 50 & 0 & 15 & 0 & 2000 & 100 \\
\hline 5 & Bhadratar-1, Ghattekhola & NBHD-2 & 100 & 0 & 20 & 0 & 1500 & 0 \\
\hline 6 & Gyanphedi-5 & NGH-3 & 180 & 0 & 0 & 0 & 2000 & 50 \\
\hline 7 & Gyanphedi-5 & NGH-1 & 80 & 0 & 0 & 1000 & 0 & 100 \\
\hline 8 & Gyanphedi-3 & NGH-2 & 50 & 0 & 40 & 2000 & 3000 & 50 \\
\hline 9 & Gaukharka-7 & NGA-1 & 20 & 8 & 0 & 0 & 4000 & 0 \\
\hline 10 & Gerkhu 8, Guhikhola (Barugau) & NGK-1 & 40 & 8 & 15 & 0 & 100 & 50 \\
\hline 11 & Hallekalika 5, Birtathok (Mayu). & NHK-6 & 300 & 2 & 250 & 0 & 0 & 0 \\
\hline 12 & Bageshowri 6 & NBG-5 & 200 & & 100 & & 300 & \\
\hline 13 & Kalyanpur 7, Kagune & NKP-4 & 50 & 0 & 35 & 0 & 400 & 0 \\
\hline 14 & Kahule-2 and Balche-2 & NKL-1, NBH-1 & 100 & 0 & 0 & 0 & 2000 & 200 \\
\hline 15 & Kalibas 3,9, Keurini, Vasvase & NKBS-1 & 70 & 8 & 0 & 0 & 3000 & 50 \\
\hline 16 & Khanigau-6, 7 and 9 & NKG-3 & 60 & 0 & 15 & 6000 & 3000 & 500 \\
\hline 17 & Lachyan 9, Phautpur & NLC-6 & 220 & 0 & 0 & 0 & 5000 & 400 \\
\hline 18 & Lachyang 5, Salyandada & NSL-1 & 70 & 0 & 0 & 1000 & 400 & 200 \\
\hline 19 & Mahakali 4, Serabagar & NMH-2 & 40 & 5 & 20 & 0 & 800 & 0 \\
\hline 20 & Mahakali 4, Mulabari & NMH-1 & 60 & 4 & 0 & 4000 & 0 & 0 \\
\hline 21 & Salme 4,5, Tarsing Khola & NS-1 & 60 & 6 & 30 & 0 & 3000 & 0 \\
\hline 22 & Samundratra-5 & NST-4 & 50 & 3 & 20 & 0 & 2000 & 50 \\
\hline 23 & Narjamandap-2 Sahare & NNM-7 & 40 & 5 & 30 & 0 & 2000 & 60 \\
\hline 24 & Gorsyang-6, Pakhari & NGS-6 & 110 & 6 & 0 & 0 & 5000 & 40 \\
\hline 25 & Bungtang-1, Barchet & NBT-2 & 150 & 0 & 0 & 0 & 10000 & 50 \\
\hline 26 & Kaule-1, Khursanibari & NKL-2 & 65 & 0 & 30 & 0 & 0 & 200 \\
\hline 27 & Bageswori-2, Gogane & NBG-6 & 75 & 0 & 0 & 0 & 4000 & 100 \\
\hline 28 & Narjamandap-7, Dotel & NNM-8 & 115 & 0 & 10 & 0 & 6000 & 200 \\
\hline 29 & Narjamandap-6, Samantole & NNM-9 & 110 & 0 & 0 & 0 & 20000 & 150 \\
\hline 30 & Narjamandap-7, Puwakhok & NNM-10 & 100 & 0 & 0 & 0 & 4000 & 100 \\
\hline 31 & Narjamandap-4, Sathyya & NNM-11 & 200 & 0 & 20 & 0 & 5000 & 200 \\
\hline 32 & Kabilas8-Sikre & NKBS-2 & 100 & 0 & 50 & 0 & 1000 & 50 \\
\hline 33 & Madanpur-9, Simkuna & NMP-4 & 40 & 3 & 20 & 0 & 2000 & 30 \\
\hline 34 & Jiling-2, Jiling & NJI-1 & 100 & 0 & 20 & 0 & 5000 & 200 \\
\hline 35 & Gorsyang-2 Kapre & NGS-7 & 65 & 10 & 0 & 0 & 2000 & 50 \\
\hline 36 & Lachyang -5 & NLC-7 & 50 & 5 & 30 & 0 & 3000 & 50 \\
\hline 37 & Lachyang-7, Shyamran/Kaule & NLC-8 & 30 & 4 & 50 & 0 & 5000 & 100 \\
\hline 38 & Urleni-4 & NUR-1 & 65 & 1 & 0 & 3000 & 3000 & 100 \\
\hline 39 & Lachyang-8 & NLC-9 & 55 & 0 & 0 & 0 & 10000 & 300 \\
\hline 40 & Kakani-4, Devithan & NKK-4 & 40 & 0 & 20 & 0 & 0 & 0 \\
\hline 41 & Likhu-8, Hille & NLI-1 & 25 & 3 & 10 & 0 & 2000 & 50 \\
\hline 42 & Gaunkharkha-7, Tallo Takpasang & NGA-3 & 55 & 3 & 0 & 0 & 4000 & 25 \\
\hline 43 & Talakhu, Tallo Dandakharkha & NTA-1 & 105 & 0 & 25 & 0 & 5000 & 100 \\
\hline 44 & Ralukadevi-2, Chilaunegaun & NRK-1 & 75 & 3 & 23 & 0 & 1000 & 100 \\
\hline 45 & Chauthe-3, Patlegaun & $\mathrm{NCH}-1$ & 25 & 2 & 15 & 0 & 1000 & 100 \\
\hline
\end{tabular}




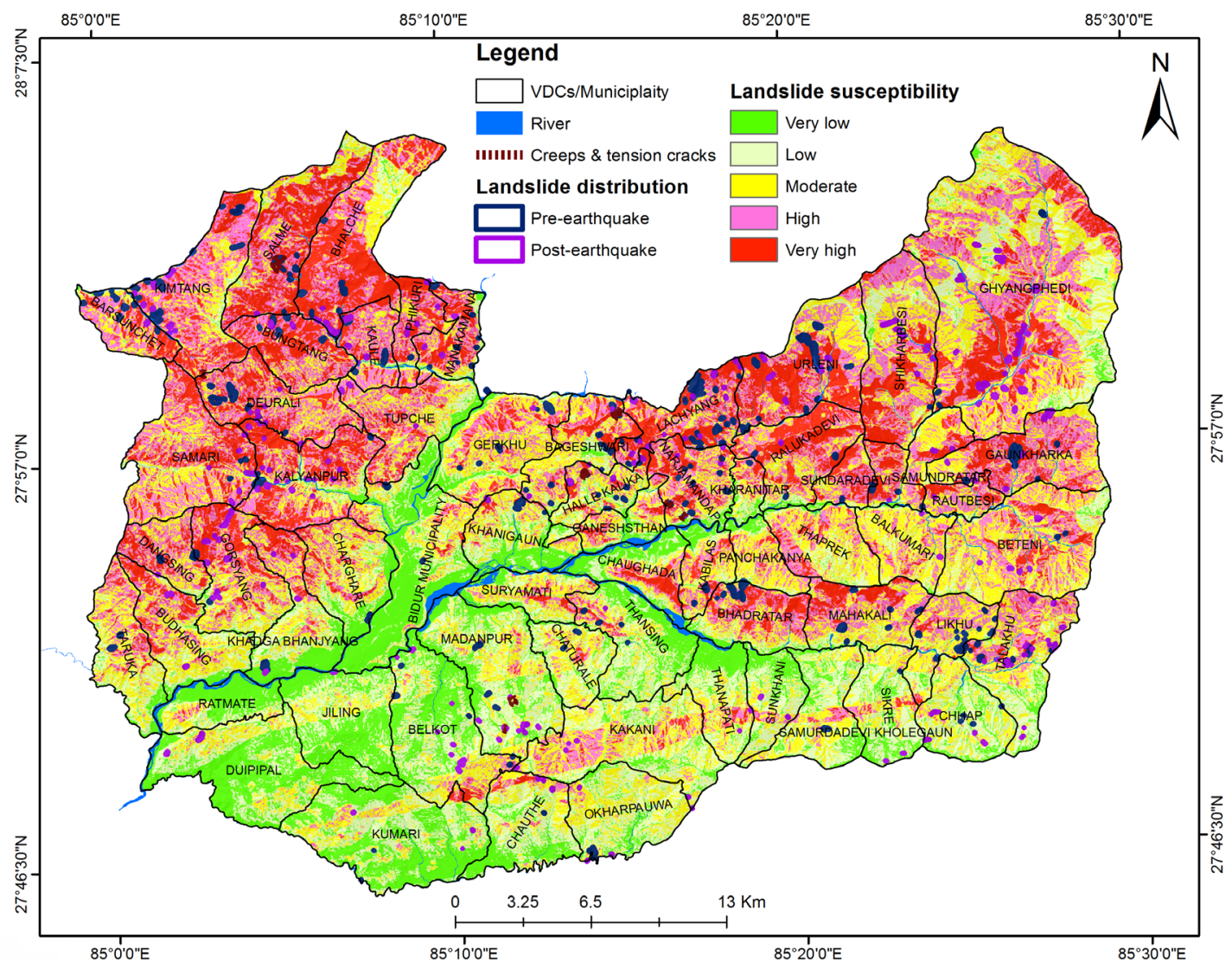

Fig. 5: Spatial distribution of landslide susceptibility zones.

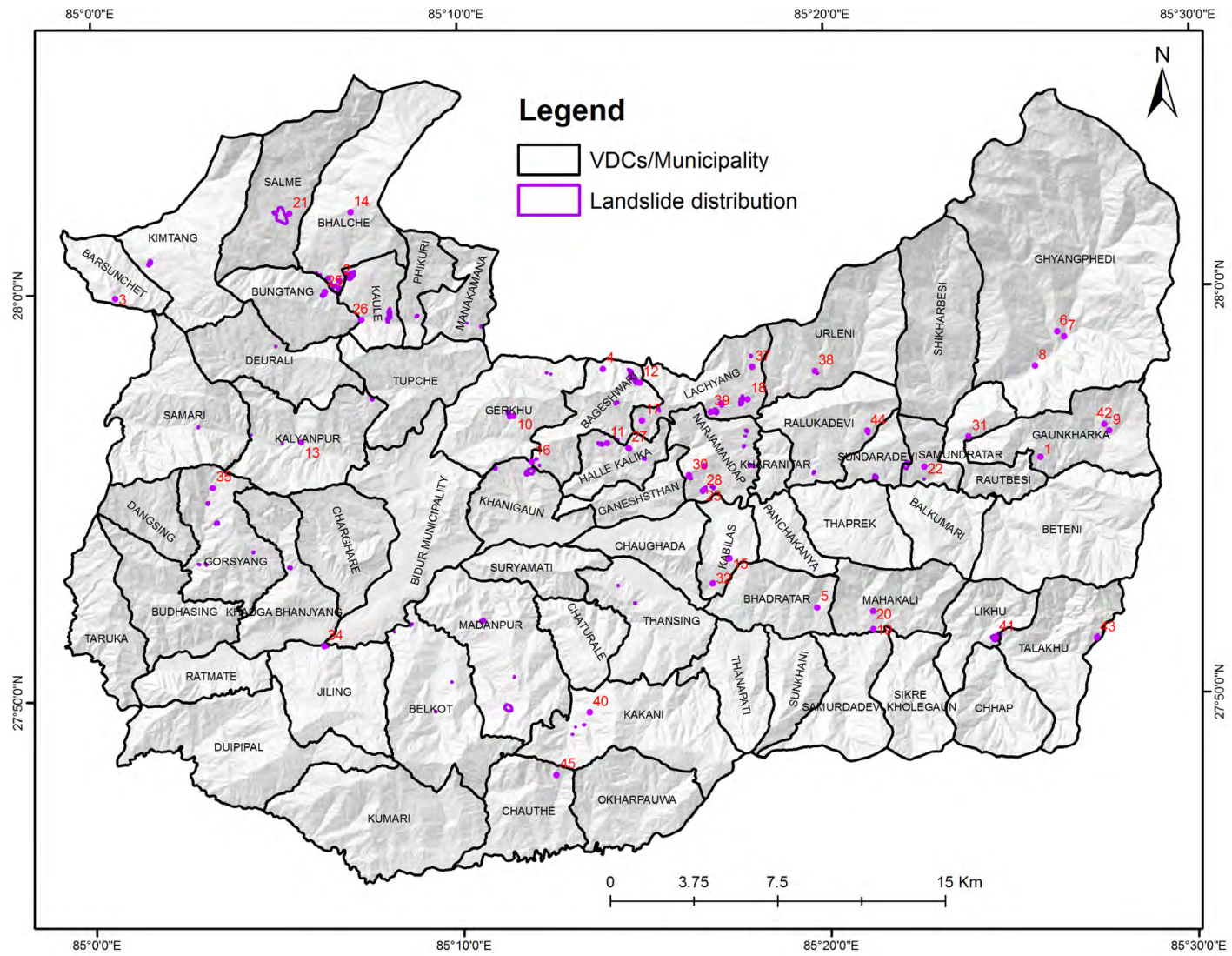

Fig. 6: Spatial distribution of prioritized landslides (Numbers indicate S. N. enlisted in Table 5). 


\section{ACKNOWLEDGEMENTS}

We are grateful for the support of the Government of Nepal and USAID supported Hariyo Ban Program. The contents of this study are the responsibility of the authors and do not necessarily reflect the views of USAID or the United States Government.

\section{REFERENCES}

Brabb, E. E., 1984, Innovative approaches to landslide hazard mapping. $4^{\text {th }}$ International Symposium on Landslides, 16-21 September, Toranto, Canada, pp. 307-324.

Deoja B., Dhital, M., Thapa, B., and Wagner, A. (Eds.), 1991, Mountain Risk Engineering Handbook. International Centre for Integrated Mountain Development (ICIMOD), Kathmandu. $875 \mathrm{p}$.

Dhital, M. R., 2005, Landslide investigation and mitigation in Himalayas: focus on Nepal. Proc. International Symposium "Landslide Hazard in Orogenic Zone from the Himalaya to Island Arc in Asia", 25-26 September, Kathmandu, Nepal, pp.1-15.

DSCWM, 2016, Guideline on landslide treatment and mitigation.
Department of Soil Conservation and Watershed Management, Kathmandu, Nepal.

Gerrard, J., 1994, The landslide hazard in the Himalayas: geological control and human action. Geomorphology, pp. 221-230.

Howell, J., 1999, Roadside Bio-engineering. Site Handbook. Published by His Majesty's Government of Nepal and DFID, $\mathrm{UK}, 160 \mathrm{p}$.

Larsen, M. C., 2001, Evaluation of temporal factors that control the susceptibility of rainfall triggered landslide. In Handmer, J. \& Gruntfest, E., Coping with Flash Floods. Netherlands: Kluwer Academic Publishers, pp. 277-288.

Lee, S., and Pradhan, B., 2006, Probabilistic landslide hazards and risk mapping on Penang Island, Malaysia. Earth System Science, v. 115(6), pp. 661-672.

MoHA, and DPNet, 2015, Nepal Disaster Report 2015. Published by the Government of Nepal, Ministry of Home Affairs (MoHA) and Disaster Preparedness Network-Nepal (DPNet-Nepal), 7 p.

Petley, D., 2012, Global patterns of loss of life from landslides, Geology, v. 40(10), pp. 927-930. http://geology.gsapubs.org/ content/40/10/927.full.pdf +html

van Westen, C. J., 1997, Statistical landslide hazard analysis, ILWIS 2.1 for Windows application guide, ITC Publication, Enschede: pp. 73-84. 